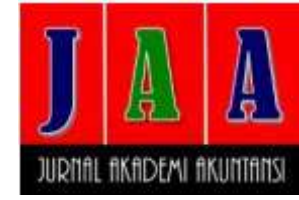

Diterima : 3 Mei 2019

Direview : 4 Mei 2019

Direvisi : 19 Mei 2019

Diterima : 20 Mei 2019

Artikel ini tersedia di website :

http://ejournal.umm.ac. id/index.php/jaa

\section{SISTEM PENGENDALIAN INTERN PEMERINTAH ATAS AKUNTABILITAS PENGELOLAAN KEUANGAN DANA DESA DI KECAMATAN SEMBAWA}

\author{
Rita Martini*, Naufal Lianto, Sukmini Hartati, Zulkifli Zulkifli, \\ Endah Widyastuti \\ Jurusan Akuntansi \\ Politeknik Negeri Sriwijaya \\ Jalan Srijaya Negara, Palembang
}

*Corresponding author: ritamartini@polsri.ac.id

The purpose of this research was to analysis the influence of government internal control system (GICS), consists of the control environment, risk assessment, control activities, information and communication, and monitoring control to accountability of village fund finance management. Sample was determined by using purposive sampling that were village government who holds a position in finance village fund in Sembawa District Banyuasin Regency, South Sumatra Province. The data were collected through questionnaires. The respondents are the head of the village, the secretary of the village, the treasurer of the village, section head, and village consultative agency. The data were analyzed by multiple linear regressions. The results showed that partially and simultaneously GICS components have significant effect on the accountability of village fund finance management.

Keywords: government intern control system, accountability, village fund

\section{PENDAHULUAN}

Pemberian dana ke desa yang besar tentunya menuntut tanggung jawab yang besar pula. Pengalokasi dana desa dari pemerintah pusat pada tahun 2015 sebesar Rp 20,7 trilyun untuk 74.093 desa, di tahun 2016 sebesar Rp 46,9 triliyun untuk 74.754 desa yang tersebar di seluruh Indonesia. Pada tahun 2017 meningkat menjadi Rp 60 trilyun dengan rata-rata setiap desa sebesar Rp 800 Juta (Gambar 1). 


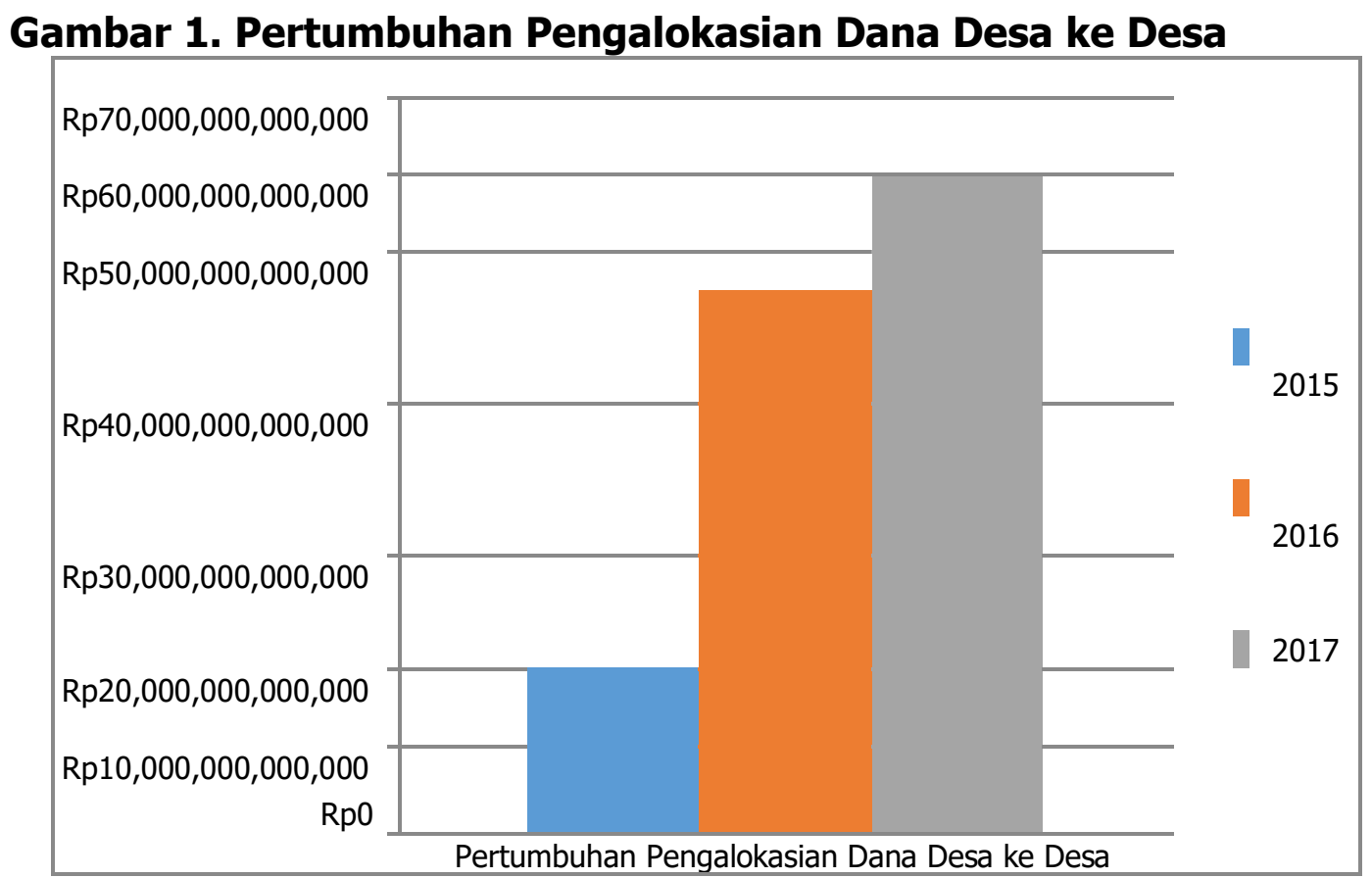

Sumber: Kementerian Keuangan RI. 2017 (diolah); (Hartati, Martini, Zulkifli, \& Widyastuti, 2018)

Peningkatan dana tiap tahunnya membutuhkan pengelolaan keuangan desa yang akuntabel. Pengelolaan keuangan desa yang akuntabel merupakan pengelolaan keuangan yang bisa dipertanggungjawakan mulai dari kegiatan perencanaan, pelaksanaan, penatausahaan, hingga pelaporan keuangan desa. Terwujudnya akuntabilitas merupakan tujuan utama dari reformasi sektor publik. Secara umum, akuntabilitas merupakan sebuah bentuk kewajiban untuk mempertanggungjawabkan sebuah keberhasilan atau kegagalan pelaksanaan organisasi dalam mencapai sasaran yang telah diterapkan untuk periode-periode sebelumnya yang dilakukan secara periodik (Mustofa, 2012).

Peraturan Menteri Dalam Negeri (Permendagri) nomor 113 tahun 2014 tentang pengelolaan keuangan desa menjelaskan pengelolaan keuangan desa adalah keseluruhan kegiatan yang meliputi perencanaan, pelaksanaan, penatausahaan, pelaporan, dan pertanggungjawaban keuangan desa. Keuangan desa dikelola berdasarkan asas-asas transparan, akuntabel, partisipatif serta dilakukan dengan tertib dan disiplin anggaran. Pengelolaan keuangan desa, dikelola dalam masa 1 (satu) tahun anggaran mulai 1 Januari sampai dengan 31 Desember. Suatu organisasi sektor publik dalam mengelola dana masyarakat dituntut harus mampu memberikan laporan keuangan yang bisa dipertanggungjawabkan. Kepala Desa menjadi penanggung jawab pengelolaan keuangan dan aset desa.

Dalam kebijakan dana desa, pemerintah pusat telah merealisasikan penyaluran dana desa kepada pemerintah desa. Dana desa tersebut telah disalurkan oleh Kementerian Keuangan (Kemenkeu). Setelah disalurkan, Kementerian Desa, Pembangunan Daerah Tertinggal, dan Transmigrasi 
(Kemendesa PDTT) bertugas mengawal prioritas penggunaan dana desa agar sesuai dengan Peraturan Menteri yang telah ditetapkan.

Untuk mencapai akuntabilitas pengelolaan keuangan desa maka diperlukan pengendalian atas kegiatan yang dilakukan. Pengendalian dilaksanakan dengan berpedoman kepada sistem pengendalian intern pemerintah (SPIP), dimana fungsi sistem pengendalian intern sebagai pedoman penyelenggaraan dan tolok ukur pengujian efektifitas penyelenggaraan kegiatan-kegiatan suatu organisasi dengan mempertimbangkan aspek biaya dan manfaat, sumber daya manusia, kejelasan kriteria pengukuran efektifitas dan perkembangan teknologi serta dilakukan secara komprehensif (Romney et al., 2014).

Seluruh instansi pemerintah wajib untuk menyelenggarakan SPIP (Republik Indonesia, 2008). Menindak lanjuti peraturan tersebut Kemendes PDTT mengeluarkan Peraturan Menteri (Permen) nomor 19 tahun 2015 tentang Penyelenggaraan SPIP (Indonesia, 2015), dan Keputusan Menteri (Kepmen) nomor 3 tahun 2016 tentang Petunjuk Pelaksanaan Penyelenggaraan SPIP di Kemendes PDTT. Terdapat beberapa prinsip yang harus diperhatikan dalam penerapan SPIP di Kemendes PDTT, (1) sistem pengendalian intern sebagai proses yang integral dan menyatu dengan kegiatan dan dilaksanakan secara terusmenerus; (2) dipengaruhi oleh manusia dalam memberikan kontribusi yang positif untuk melaksanakannya; (3) memberikan keyakinan yang memadai bukan keyakinan yang mutlak, dan (4) diterapkan sesuai dengan kebutuhan ukuran, kompleksitas, sifat kerja dan fungsi kementerian.

Pengendalian internal merupakan sistem/prosedur yang ada dalam suatu organisasi untuk menjaga proses kegiatan operasi sesuai dengan kebijakan yang telah ditetapkan guna pencapaian tujuan organisasi itu sendiri. Pengendalian internal berisi rencana organisasi dan metode yang digunakan untuk menjaga atau melindungi aktiva dan menghasilkan informasi yang akurat dan dapat dipercaya (Krismiaji, 2010) dan (Martini, Sari, \& Wardhani, 2015).

Peran pemerintah desa dalam mengelola keuangan desa merupakan bentuk pelayanan kepada masyarakat desa dengan menyajikan laporan keuangan yang akuntabel, memberikan informasi keuangan secara terbuka dan memberikan pengawasan dalam proses pengelolaan keuangan agar menghasilkan pengelolaan keuangan yang dapat dipertanggungjawabkan. Jadi pemerintah desa menjalankan tugasnya untuk kepentingan dan kesejahteraan masyarakat desa. Hal ini sesuai dengan stewardship theory, yaitu tugas pemerintah menyajikan laporan keuangan, memberikan aksesibilitas laporan keuangan dan sistem pengendalian internal merupakan bentuk pelayanan kepada masyarakat desa. Stewardship theory describes a situation or condition in which management is not motivated by individual goals but rather prioritizes the interests of the organization (Davis, Schoorman, \& Donaldson, 1991) 
Terdapat hambatan penyaluran dana desa pada sebagian desa di beberapa kecamatan yang berada pada wilayah kabupaten Banyuasin, diantaranya Kecamatan Sembawa Kabupaten Banyuasin, pada tahun 2016. Hambatan penyaluran tersebut menyebabkan tersendatnya pencairan dana desa untuk tahun selanjutnya. Menurut pihak kecamatan yang bersangkutan, hal ini dikarenakan terlambatnya pihak desa untuk melaporkan Surat Pertanggung Jawaban (SPJ) untuk dana desa. Akibat keterlambatan tersebut bisa mempengaruhi proyeksi pembangunan di wilayah kecamatan Sembawa (www.detiksumsel.com, 2016). Kurangnya kesadaran pihak desa dalam melakukan kewajibannya membuat SPJ menyebabkan pengalokasian dana desa untuk kecamatan tersebut terhambat.

Kurangnya akuntabilitas pelaporan pengelolaan dana desa di setiap desa, serta terjadinya penghambatan penyaluran alokasi dana desa yang terjadi di wilayah kecamatan Sembawa akibat dari terlambatnya pihak aparatur desa dalam melaporkan SPJ dana desa kepada pihak kecamatan. Pemerintahan desa (Aditama, 2000) seharusnya tepat waktu dalam pembuatan surat pertanggungjawaban dana desa sebagai bahan pelaporan mengenai dana desa yang telah dikelolanya, karena pemerintah merupakan entitas pelapor yang harus membuat laporan keuangan sebagai bentuk pertanggungjawabannya.

Penelitian ini bertujuan menganalisis pengaruh SPIP yang terdiri dari lingkungan pengendalian, penilaian risiko, kegiatan pengendalian, sistem informasi dan komunikasi, serta pemantauan, secara parsial dan simultan terhadap akuntabilitas pengelolaan keuangan dana desa. Tata kelola yang baik salah satunya dipengaruhi oleh efektifitas pengendalian intern (Martini, Sari, \& Wardhani, 2015) dan (Martini, Sari, Maria, \& Thoyib, 2016).

Penelitian terdahulu yang mengkaji pengaruh SPIP terhadap akuntabilitas pengelolaan keuangan dana desa (Fajri, Setyowati, \& Siswidiyanto, 2017); (Yudianto \& Ekasari, 2017); dan (Widyatama, Lola, \& Diarespati, 2017), membuktikan SPIP berpengaruh terhadap akuntabilitas pengelolaan keuangan dana desa. Untuk mendukung akuntabilitas, dibutuhkan adanya sistem pengendalian intern yang baik serta dapat dipertanggungjawabkan (Sari, 2017). Memperkuat akuntabilitas sektor publik sebagai konsekuensi penting dari kebijakan pemerintah (Afiah \& Azumi, 2015).

Paparan pada tulisan ini dimulai dengan pendahuluan, dilanjutkan dengan kajian teori, metode penelitian, serta hasil penelitian dan pembahasan. Pada bagian akhir, berisi kesimpulan dan saran bagi pihakpihak terkait.

\section{TINJAUAN LITERATUR DAN PENGEMBANGAN HIPOTESIS Pemerintah Desa}

Pemerintahan desa diselenggarakan oleh pemerintah desa. Kewenangan desa meliputi kewenangan di bidang penyelenggaraan pemerintahan desa, pelaksanaan pembangunan desa, pembinaan 
kemasyarakatan desa, dan pemberdayaan masyarakat desa berdasarkan prakarsa masyarakat, hak asal usul, dan adat istiadat desa (UU nomor 6 tahun 2014 pasal 18).

Pemerintahan desa (Republik Indonesia, 2005) adalah penyelenggaraan urusan pemerintahan oleh pemerintah desa dan badan permusyawaratan desa dalam mengatur dan mengurus kepentingan masyarakat setempat berdasarkan asal-usul dan adat istiadat setempat yang diakui dan dihormati dalam sistem Pemerintahan Negara Kesatuan Republik Indonesia. Pemerintah desa adalah kepala desa dibantu perangkat desa sebagai unsur penyelenggara pemerintahan desa. Kekuasaan pengelolaan keuangan desa dipegang oleh kepala desa. Dalam siklus pengelolaan keuangan desa (Republik Indonesia, 2004) merupakan tanggung jawab dan tugas dari kepala desa dan pelaksana teknis pengelolaan keuangan desa (sekretaris desa, kepala seksi dan bendahara desa).

\section{Sistem Pengendalian Internal (SPIP)}

SPIP ialah proses yang integral pada tindakan dan kegiatan yang dilakukan secara terus menerus oleh pimpinan dan seluruh pegawai untuk memberikan keyakinan yang memadai atas tercapainya tujuan organisasi melalui kegiatan yang efektif dan efisien, keandalan pelaporan keuangan, pengamanan aset negara, dan ketaatan terhadap peraturan perundang-undangan (Republik Indonesia, 2008). Unsur SPIP terdiri atas: (1) lingkungan pengendalian, (2) penilaian risiko, (3) kegiatan pengendalian, (4) informasi dan komunikasi, dan (5) pemantauan pengendalian intern.

\section{Akuntabilitas Pengelolaan Keuangan Daerah}

Akuntabilitas (LAN dan BPKP, 2000), adalah kewajiban untuk memberikan pertanggungjawaban atau untuk menjawab dan menerangkan kinerja dan tindakan seseorang/badan hukum/pimpinan kolektif suatu organisasi kepada pihak yang memiliki hak atau berkewenangan untuk meminta keterangan atau pertanggungjawaban. Akuntabilitas keuangan merupakan pertanggungjawaban mengenai integritas keuangan, pengungkapan dan ketaatan terhadap peraturan perundang-undangan. Sasaran pertanggungjawaban adalah laporan keuangan yang disajikan dan peraturan perundang-undangan yang berlaku yang mencakup penerimaan, penyimpanan, pengeluaran oleh instansi pemerintah.

Akuntabilitas juga merupakan instrumen untuk kegiatan pengendalian terutama pencapaian hasil kepada pelayanan publik, disamping itu akuntabilitas merupakan suatu evalusi kegiatan yang dilaksanakan oleh seorang petugas baik masih berada dalam jalur otoritasnya atau sudah berada di luar jauh tanggungjawab dan kewenangannya. Selanjutnya akuntabilitas juga berorientasi kepada pencapaian visi dan misi serta hasil dan manfaat yang diperoleh, dapat 
menunjukan tingkat pencapaian tujuan dan sasaran yang telah ditetapkan.

Akuntabilitas harus jujur, objektif, transparan dan inovatif sebagai katalisator perubahan managemen instansi pemerintah dalam bentuk pemutakhiran metode dan teknik pengukuran kinerja dan penyusunan laporan akuntabilitas. Peraturan Pemerintah Nomor 58 Tahun 2005, menyebutkan pengelolaan keuangan daerah adalah keseluruhan kegiatan yang meliputi perencanaan, pelaksanaan, penatausahaan, pelaporan, pertanggungjawaban dan pengawasan keuangan daerah. Akuntabilitas merupakan dasar pelaporan keuangan di pemerintahan yang didasari oleh adanya hak masyarakat untuk mengetahui dan menerima penjelasan atas pengumpulan sumber daya dan penggunaannya. Dasar dan bentuk pelaporan keuangan pemerintahan di negara kesatuan Republik Indonesian diatur di dalam Peraturan Pemerintah Nomor 71 Tahun 2010 tentang Standar Akuntansi Pemerintahan (Republik Indonesia, 2010).

Karakteristik adalah ukuran-ukuran normatif perlu diwujudkan dalam informasi akuntansi sehingga dapat memenuhi tujuan laporan akuntansi, yaitu: menyediakan informasi tentang sumber, alokasi dan penggunaan sumber daya keuangan, menyediakan informasi mengenai kecukupan penerimaan periode berjalan untuk membiayai seluruh pengeluaran, menyediakan informasi mengenai jumlah sumber daya ekonomi yang digunakan dalam kegiatan entitas pelaporan serta hasilhasil yang telah dicapai, menyediakan informasi mengenai bagaimana entitas pelaporan mendanai seluruh kegiatannya dan mencukupi kebutuhan kasnya, menyediakan informasi mengenai posisi keuangan dan kondisi entitas pelaporan berkaitan dengan sumber-sumber penerimaannya, baik jangka pendek maupun jangka panjang, termasuk yang berasal dari pungutan pajak dan pinjaman, menyediakan informasi mengenai perubahan posisi keuangan entitas pelaporan, apakah mengalami kenaikan atau penurunan, sebagai akibat kegiatan yang dilakukan selama periode pelaporan.

Dimensi akuntabilitas finansial (Mardiasmo, 2002), yaitu dimensi yang mengharuskan lembaga-lembaga publik untuk membuat laporan keuangan untuk menggambarkan kinerja finansial organisasi kepada pihak luar. Dimensi akuntabilitas (Rasul, 2002), yaitu akuntabilitas hukum dan kejujuran, akuntabilitas manajerial, akuntabilitas program, akuntabilitas kebijakan, dan akuntabilitas finansial.

Akuntabilitas finansial merupakan pertanggungjawaban lembaga lembaga publik untuk menggunakan dana publik secara ekonomis, efisien dan efektif, tidak ada pemborosan dan kebocoran dana, serta korupsi. Akuntabilitas mengharuskan lembaga-lembaga publik untuk membuat laporan keuangan untuk menggambarkan kinerja finansial organisasi kepada pihak luar (Martini, Zulkifli, Hartati, \& Armaini, 2018).

Semakin meningkatnya tuntutan masyarakat terhadap penyelenggaraan pemerintahan yang baik dan bersih telah mendorong pengembangan dan penerapan sistem pertanggungjawaban yang jelas, 
tepat, teratur, dan efektif yang dikenal dengan Sistem Akuntabilitas Kinerja Instansi Pemerintah (SAKIP). Penerapan sistem tersebut bertujuan agar penyelenggaraan pemerintahan dan pembangunan dapat berlangsung secara berdaya guna, berhasil guna, bertanggung jawab dan bebas dari praktik kolusi, korupsi, dan nepotisme (Riantiarno \& Azlina, 2011).

Akuntabilitas pengelolaan keuangan daerah merupakan proses pengelolaan keuangan daerah mulai dari perencanaan, pelaksanaan, penatausahaan, pertanggungjawaban, serta pengawasan harus benar-benar dapat dilaporkan dan dipertanggungjawabkan kepada masyarakat dan DPRD terkait dengan kegagalan maupun keberhasilannya sebagai bahan evaluasi tahun berikutnya. Masyarakat tidak hanya memiliki hak untuk mengetahui pengelolaan keuangan tetapi berhak untuk menuntut pertanggungjawaban atas pengaplikasian serta pelaksanaan pengelolaan keuangan daerah tersebut (Halim, 2007).

Akuntabilitas pengelolaan keuangan daerah merupakan pertanggungjawaban mengenai integritas keuangan, pengungkapan dan ketaatan terhadap peraturan perundang-undangan. Sasarannya adalah laporan keuangan yang mencakup penerimaan, penyimpanan dan pengeluaran keuangan instansi pemerintah daerah.

Instrumen utama dari akuntabilitas pengelolaan keuangan keuangan daerah adalah anggaran pemerintah daerah, data yang secara periodik dipublikasikan, laporan tahunan dan hasil investigasi dan laporan umum lainnya yang disiapkan oleh agent yang independen. Anggaran tahunan secara khusus mempunyai otoritas legal untuk pengeluaran dana publik, sehingga proses penganggaran secara keseluruhan menjadi relevan untuk manajemen fiskal dan untuk melaksanakan akuntabilitas pengelolaan keuangan dan pengendalian pada berbagai tingkat operasi (LAN, 2000).

Dalam Peraturan Pemerintah No. 58 Tahun 2005 (Pasal 1), keuangan daerah adalah semua hak dan kewajiban daerah dalam rangka penyelenggaraan pemerintahan daerah yang dapat dinilai dengan uang, termasuk didalamnya segala bentuk kekayaan yang berhubungan dengan hak dan kewajiban daerah terebut. Bila dilihat dari ruang lingkupnya, keuangan daerah meliputi kekayaan daerah yang dikelola langsung

oleh pemerintah daerah dan kekayaan daerah yang dipisahkan pengurusannya. Kekayaan daerah yang dikelola langsung oleh pemerintah daerah meliputi APBD dan barang-barang inventaris milik daerah. Kekayaan daerah yang dipisahkan pengurusannya meliputi badan-badan usaha milik daerah (Halim, 2007).

\section{Pengertian Pengelolaan Keuangan Dana Desa}

Keuangan desa (Republik Indonesia, 2014) adalah hak dan kewajiban desa yang dapat dinilai dengan uang serta segala sesuatu berupa uang dan barang yang berhubungan dengan pelaksanaan hak dan kewajiban desa. Pada ayat (2) dinyatakan adanya hak dan kewajiban 
akan menimbulkan pendapatan, belanja, pembiayaan, dan pengelolaan keuangan desa. Pasal 93 ayat (1) UU nomor 6 tahun 2014 menyatakan pengelolaan keuangan desa meliputi: perencanaan, pelaksanaan, penatausahaan, pelaporan, dan pertanggungjawaban (Republik Indonesia, 2014).

\section{Hipotesis Penelitian}

$\mathrm{H} 1$ : Lingkungan pengendalian berpengaruh terhadap akuntabilitas pengelolaan keuangan dana desa

$\mathrm{H} 2$ : Penilaian risiko berpengaruh terhadap akuntabilitas pengelolaan keuangan dana desa

H3: Kegiatan pengendalian berpengaruh terhadap akuntabilitas pengelolaan keuangan dana desa

H4: Informasi dan komunikasi berpengaruh terhadap akuntabilitas pengelolaan keuangan dana desa

H5: Pemantauan berpengaruh terhadap akuntabilitas pengelolaan keuangan dana desa

H6: Secara simultan lingkungan pengendalian, penilaian risiko, kegiatan pengendalian, informasi dan komunikasi, pemantauan berpengaruh terhadap akuntabilitas pengelolaan keuangan dana desa

\section{METODE PENELITIAN}

Populasi penelitian meliputi seluruh kepala desa, sekretaris desa, bendahara desa, kepala seksi dan badan permusyawaratan desa di 11 desa yang ada di kecamatan Sembawa Kabupaten Banyuasin provinsi Sumatera Selatan, berjumlah 55 orang. Semua populasi dijadikan sampel penelitian (sampel jenuh).

Tabel 1. Populasi dan Sampel

\begin{tabular}{|c|c|c|c|c|c|c|}
\hline \multirow[b]{2}{*}{ No } & \multirow[b]{2}{*}{ Nama Desa } & \multicolumn{5}{|c|}{ Responden } \\
\hline & & $\begin{array}{c}\text { Kepala } \\
\text { Desa }\end{array}$ & \begin{tabular}{|c|} 
Sekretaris \\
Desa
\end{tabular} & $\begin{array}{c}\text { Bendahara } \\
\text { Desa }\end{array}$ & $\begin{array}{l}\text { Kasi } \\
\text { Desa }\end{array}$ & $\begin{array}{c}\text { Badan } \\
\text { Permusyawaratan } \\
\text { Desa }\end{array}$ \\
\hline 1 & Lalang Sembawa & 1 & 1 & 1 & 1 & 1 \\
\hline 2 & Limau & 1 & 1 & 1 & 1 & 1 \\
\hline 3 & Limbang Mulya & 1 & 1 & 1 & 1 & 1 \\
\hline 4 & Mainan & 1 & 1 & 1 & 1 & 1 \\
\hline 5 & Muara Damai & 1 & 1 & 1 & 1 & 1 \\
\hline 6 & Pulau Harapan & 1 & 1 & 1 & 1 & 1 \\
\hline 7 & Pulau Muning & 1 & 1 & 1 & 1 & 1 \\
\hline 8 & Purwosari & 1 & 1 & 1 & 1 & 1 \\
\hline 9 & Rejodadi & 1 & 1 & 1 & 1 & 1 \\
\hline 10 & Santansari & 1 & 1 & 1 & 1 & 1 \\
\hline 11 & Suka Makmur & 1 & 1 & 1 & 1 & 1 \\
\hline
\end{tabular}




\begin{tabular}{|l|l|l|l|l|l|l|} 
& & & & & \\
\hline & Total Penyebaran & 11 & 11 & 11 & 11 & 11 \\
\hline
\end{tabular}

Sumber: (Hartati, Martini, Zulkifli, \& Widyastuti, 2018)

Variabel dependen adalah akuntabilitas pengelolaan keuangan dana desa. Variabel independen adalah SPIP, meliputi lingkungan pengendalian, penilaian risiko, kegiatan pengendalian, informasi dan komunikasi, pemantauan. Masing-masing variabel diukur dengan skala Likert.

Teknik analisis data dengan metode Regresi Linear Berganda berbantuan program Statistical Product of Service Solution (SPSS) for windows, dengan persamaan berikut:

Keterangan:

$$
A P D D=a+b_{1} L P+b_{2} P R+b_{3} K P+b_{4} I K+b_{5} P T+e
$$

APDD = Akuntabilitas Pengelolaan Dana Desa

$\mathrm{LP} \quad=$ Lingkungan Pengendalian

$\mathrm{PR} \quad=$ Penaksiran Risiko

$\mathrm{KP} \quad=$ Kegiatan Pengendalian

IK = Informasi dan Komunikasi

PT = Pemantauan

\section{HASIL DAN PEMBAHASAN}

\section{Hasil Uji Signifikansi Parsial (uji t)}

Uji t atau uji koefisien regresi secara parsial digunakan untuk mengetahui apakah secara parsial variabel independen berpengaruh secara signifikan atau tidak terhadap variabel dependen (hasil uji t pada Tabel 1).

Gambaran hasil pengujian hipotesis dapat menghasilkan persamaan berikut:

$$
\begin{aligned}
& \text { APDD }=-116,885+b_{1} 1,277+b_{2} 1,079+b_{3} 2,674+b_{4} 6,735+b_{5} 5,027 \\
&
\end{aligned}
$$

Nilai signifikansi variabel lingkungan pengendalian sebesar $0,016<0,05$, disimpulkan variabel lingkungan pengendalian secara parsial berpengaruh positif dan signifikan terhadap akuntabilitas pengelolaan keuangan dana desa. Nilai signifikansi variabel penilaian risiko sebesar 0,027 <0,05, jadi variabel penilaian risiko secara parsial berpengaruh positif dan signifikan terhadap akuntabilitas pengelolan keuangan dana desa. Nilai signifikansi variabel kegiatan pengendalian sebesar $0,000<0,05$, disimpulkan variabel kegiatan pengendalian secara parsial berpengaruh positif dan signifikan terhadap akuntabilitas pengelolaan keuangan dana desa. Nilai signifikansi variabel informasi dan komunikasi sebesar 0,003 < 0,05 maka variabel informasi dan komunikasi secara parsial berpengaruh positif dan signifikan terhadap akuntabilitas pengelolaan keuangan dana desa. 
Nilai signifikansi variabel pemantauan sebesar $0,003<0,05$, artinya variabel pemantauan secara parsial berpengaruh positif dan signifikan terhadap akuntabilitas pengelolaan keuangan dana desa.

Tabel 1. Hasil Parsial ( Uji t )

Coefficients $^{\mathrm{a}}$

\begin{tabular}{|c|c|c|c|c|c|}
\hline \multirow[t]{2}{*}{ Model } & \multicolumn{2}{|c|}{$\begin{array}{l}\text { Unstandardized } \\
\text { Coefficients }\end{array}$} & \multirow{2}{*}{$\begin{array}{c}\begin{array}{c}\text { Standardized } \\
\text { Coefficients }\end{array} \\
\text { Beta }\end{array}$} & \multirow[t]{2}{*}{$\mathrm{t}$} & \multirow[t]{2}{*}{ Sig. } \\
\hline & $B$ & Std. Error & & & \\
\hline (Constant) & $-116,885$ & 26,397 & & $-4,428$ & 000 \\
\hline Lingkungan Pengendalian & 1,277 & ,510 & 219 & 2,505 & 016 \\
\hline Penaksiran Risiko & 1,079 & ,473 & , 186 & 2,279 & ,027 \\
\hline Kegiatan Pengendalian & 2,674 & ,406 & ,533 & 6,581 & ,000 \\
\hline $\begin{array}{l}\text { Informasi dan Komunikasi } \\
\text { Pemantauan }\end{array}$ & 6,735 & 2,115 & ,276 & 3,185 & ,003 \\
\hline Pengendalian & 5,027 & 1,613 & 248 & 3,116 & ,003 \\
\hline
\end{tabular}

a. Dependent Variable: Akuntabilitas Pengelolaan Keuangan Dana Desa

Sumber: (Hartati, Martini, Zulkifli, \& Widyastuti, 2018)

Hasil pengujian hipotesis, menunjukkan nilai thitung untuk lingkungan pengendalian, penaksiran risiko, kegiatan pengendalian, informasi dan komunikasi, serta pemantauan, jika dibandingkan dengan nilai ttabel adalah 2,010, maka thitung $>$ nilai ttabel. Berarti lingkungan pengendalian, penaksiran risiko, kegiatan pengendalian, informasi dan komunikasi, serta pemantauan memiliki hubungan atau berpengaruh positif dan signifikan terhadap akuntabilitas pengelolaan keuangan dana desa.

\section{Hasil Uji Koefisien Determinasi}

Hasil uji koefisien determinasi $\left(\mathrm{R}^{2}\right)$ terlihat pada output Model Sumary dari hasil analisis regresi berganda. Hasil uji koefisien determinasi $\left(R^{2}\right)$ disajikan pada tabel 2.

Tabel 2. Hasil Uji Koefesien Determinasi

Model Summaryb

\begin{tabular}{|c|r|r|r|r|}
\hline Model & \multicolumn{1}{|c|}{ R } & R Square & Adjusted R Square & Std. Error of the Estimate \\
\hline 1 &, $833^{\mathrm{a}}$ &, 694 &, 663 & 5,283 \\
\hline
\end{tabular}

a. predictors: (constant), pemantauan pengendalian, kegiatan pengendalian, penilaian risiko, informasi dan komunikasi, lingkungan pengendalian

b. dependent variable: akuntabilitas pengelolaan keuangan dana desa

Sumber: (Hartati, Martini, Zulkifli, \& Widyastuti, 2018)

Adjusted R Square sebesar 0,663, berarti variabel lingkungan pengendalian, penilaian risiko, kegiatan pengendalian, informasi dan komunikasi, pemantauan terhadap akuntabilitas pengelolaan 
keuangan dana desa yang berarti "kuat" (Gujarati, 2006). Nilai ini menginterprestasikan variabel $\mathrm{X}$ memiliki pengaruh kontribusi sebesar $66,30 \%$ terhadap variabel $Y$, sisanya $33,70 \%$ dijelaskan oleh variabel lain yang tidak termasuk dalam penelitian ini.

\section{Hasil Uji Signifikansi Simultan (uji F)}

Uji F atau uji koefisien regresi secara bersama-sama digunakan untuk mengetahui apakah secara bersama-sama variabel independen berpengaruh signifikan terhadap variabel dependen. Hasil uji $\mathrm{F}$ dapat dilihat dalam tabel 3.

\section{Tabel 3. Hasil Uji Simultan (uji F) ANOVA $^{\text {a }}$}

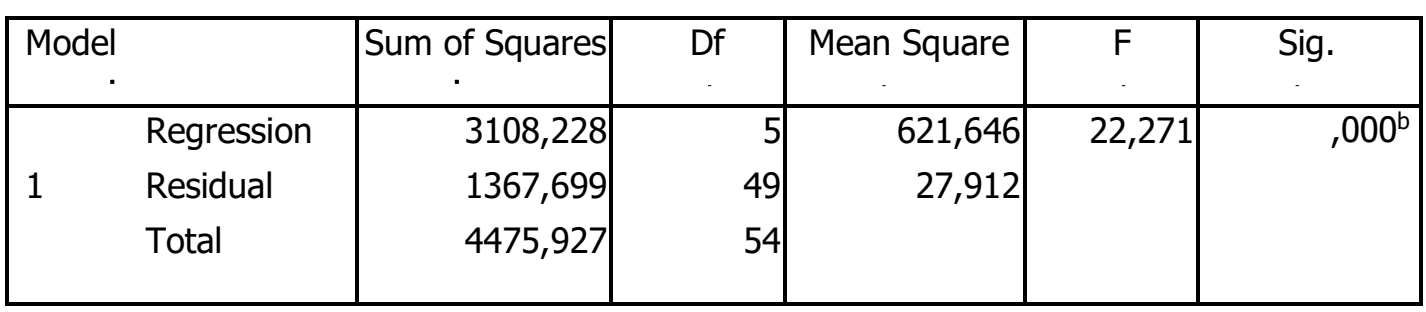

a. Dependent Variable: Akuntabilitas Pengelolaan Keuangan Dana Desa

b. Predictors: (Constant), Pemantauan, Kegiatan

Pengendalian, Penilaian Risiko, Informasi dan Komunikasi, Lingkungan Pengendalian

Sumber: (Hartati, Martini, Zulkifli, \& Widyastuti, 2018)

Nilai $F$ sebesar 22,271 dengan taraf signifikansi 0,000. Ini berarti secara simultan lingkungan pengendalian, penilaian risiko, kegiatan pengendalian, informasi dan komunikasi, pemantauan pengendalian berpengaruh positif dan signifikan terhadap akuntabilitas pengelolaan keuangan dana desa.

\section{Pembahasan}

\section{Pengaruh Lingkungan Pengendalian (LP) terhadap AKPDD}

Lingkungan pengendalian yang baik merupakan dasar untuk semua komponen pengendalian intern, mampu menetapkan corak suatu organisasi, mempengaruhi kesadaran orang-orangnya. Lingkungan pengendalian diwujudkan melalui penegakan intergritas dan nilai etika, komitmen terhadap kompetensi, kepemimpinan yang kondusif, pembentukan struktur organisasi yang sesuai dengan kebutuhan, pendelegasian wewenang dan tanggungjawab yang tepat, penyusunan dan penerapan kebijakan yang sehat tentang pembinaan sumberdaya manusia, perwujudan peran aparat pengawasan intern yang efektif, dan hubungan kerja yang baik dengan instansi pemerintah terkait. Knowledge and skill employees to innovate and have lived up the process routine companies and processes improve 
business to be more efficiency (Martini, Sulaiman, Maria, \& Pangaribuan, 2018).

Akuntabilitas dapat terwujud apabila terdapat komitmen dari pimpinan dan seluruh staf instansi pemerintah yang bersangkutan untuk menjamin penggunaan sumber daya secara konsisten dengan peraturan perundang-undangan. Accountability is required or expected to give an explanation for one action (The Oxford Advance Learner's Dictionary dalam LAN dan BPKP, 2000). Dalam akuntabilitas terkandung kewajiban untuk menyajikan dan melaporkan segala tindak tanduk dan kegiatannya terutama di bidang administrasi keuangan kepada pihak yang lebih tinggi/atasannya. Akuntabilitas dilihat dari sudut pandang pengendalian tindakan pada pencapaian tujuan. Akuntabilitas ditujukan untuk mencari jawaban terhadap pertanyaan yang berhubungan dengan pelayanan apa, siapa, kepada siapa, milik siapa, yang mana dan bagaimana. Pertanyaan yang memerlukan jawaban tersebut antara lain apa yang harus dipertanggungjawabkan, mengapa pertanggungjawaban harus diserahkan, kepada siapa pertanggungjawaban harus diserahkan, siapa yang bertanggungjawab terhadap berbagai kegiatan dalam masyarakat.

Untuk mendukung akuntabilitas, dibutuhkan adanya sistem pengendalian intern dan sistem pengendalian ekstern yang baik serta dapat dipertanggungjawabkan (Halim, 2007) dalam (Sari, 2017). Pimpinan instansi pemerintah wajib menciptakan dan memelihara lingkungan pengendalian yang menimbulkan perilaku positif dan kondusif untuk penerapan sistem pengendalian internal dalam lingkungan kerjanya (Republik Indonesia, 2008).

SPIP berpengaruh positif terhadap akuntabilitas pengelolaan keuangan desa artinya semakin diterapkannya SPIP yang salah satu unsurnya lingkungan pengendalian maka hal tersebut akan meningkatkan akuntabilitas pengelolaan keuangan dana desa (Fajri, Setyowati, \& Siswidiyanto, 2017) dan (Widyatama, Lola, \& Diarespati, 2017).

\section{Pengaruh Penilaian Risiko (PR) terhadap AKPDD}

Penaksiran resiko adalah identifikasi dan analisis terhadap resiko yang relevan untuk mencapai tujuannya, membentuk suatu dasar untuk menentukan bagaimana resiko harus dikelola. Penilaian resiko diawali dengan penetapan dan maksud tujuan instansi pemerintah yang jelas dan konsisten baik tingkat instansi maupun tingkat kegiatan, selanjutnya instansi pemerintah mengidentifikasi secara efisien dan efektif resiko yang dapat menghambat pencapaian tujuan tersebut, baik dari dalam maupun dari luar intansi. Selanjutnya dilakukan manajemen resiko dan pengendalian resiko yang diperlukan untuk memperkecil resiko. Hal tersebut diwujudkan dengan penetapan tujuan dengan jelas dan konsisten, identifikasi resiko menyeluruh, analisis resiko, dan mekanisme identifikasi resiko. 
Pimpinan instansi pemerintah wajib melakukan penilaian risiko terdiri atas: identifikasi risiko dan analisis risiko, pimpinan instansi pemerintah menetapkan penilaian risiko dalam rangka tujuan instansi pemerintah yaitu memuat pernyataan dan arahan yang spesifik, terukur, dapat dicapai, realistis, dan terikat waktu kemudian wajib dikomunikasikan kepada seluruh pegawai (Republik Indonesia, 2008). Tujuan instansi pemerintah dapat terwujud apabila pimpinan instansi pemerintah menetapkan strategi operasional yang konsisten, strategi manajemen terintegrasi, rencana penilaian risiko, dan tujuan pada tingkatan kegiatan, dengan berpedoman pada peraturan perundangundangan.

SPIP berpengaruh positif terhadap akuntabilitas pengelolaan keuangan desa artinya semakin diterapkannya SPIP yang salah satu unsurnya penilaian risiko maka hal tersebut akan meningkatkan akuntabilitas pengelolaan keuangan dana desa (Yudianto \& Ekasari, 2017) dan (Widyatama, Lola, \& Diarespati, 2017).

\section{Pengaruh Kegiatan Pengendalian (KP) terhadap APKDD}

Kegiatan pengendalian adalah kebijakan dan prosedur yang membantu menjamin arahan manajemen dilaksanakan. Kegiatan pengendalian yang diterapkan dalam suatu instansi pemerintah dapat berbeda dengan yang diterapkan oleh instansi pemerintah lain, disebabkan perbedaan visi, misi dan tujuan organisasi, lingkungan dan cara beroperasi, tingkat kerumitan organisasi, sejarah atau latar belakang serta budaya organisasi, resiko yang dihadapi organisasi. Kegiatan pengendalian yang baik diwujudkan melalui kebijakan dan mekanisme pengendalian, kebijakan dan mekanisme pengendalian, pengembangan kegiatan pengendalian, dan penerapan kegiatan pengendalian.

Pimpinan instansi pemerintah wajib menyelenggarakan kegiatan pengendalian sesuai ukuran, kompleksitas, dan sifat dari tugas dan fungsi instansi pemerintah yang bersangkutan (Republik Indonesia, 2008). SPIP berpengaruh positif terhadap akuntabilitas pengelolaan keuangan desa artinya semakin diterapkannya SPIP yang salah satu unsurnya kegiatan pengendalian maka hal tersebut akan meningkatkan akuntabilitas pengelolaan keuangan dana desa (Widyatama, Lola, \& Diarespati, 2017)

\section{Pengaruh Informasi dan Komunikasi (IK) terhadap APKDD}

Informasi dan komunikasi meliputi pengindentifikasian, penangkapan dan pertukaran informasi dalam suatu bentuk dan waktu yang memungkinkan orang melaksanakan tanggungjawabnya. Informasi relevan dan dapat diandalkan berupa informasi keuangan maupun non keuangan yang berhubungan dengan peristiwa eksternal dan internal. Informasi dan komunikasi yang baik dapat diwujudkan dengan komunikasi dengan pihak lain, informasi operasional dan 
keuangan, komunikasi sesuai dengan kebutuhan, komunikasi dikelola dan dikembangkan

Pimpinan instansi pemerintah wajib mengidentifikasi, mencatat, dan mengkomunikasikan informasi dalam bentuk dan waktu yang tepat (Republik Indonesia, 2008). Komunikasi atas informasi sebagaimana dimaksud wajib diselenggarakan secara efektif, untuk menyelenggarakan komunikasi yang efektif (Martini, Sari, \& Wardhani, 2015).

Akuntabilitas publik menjadi landasan utama proses penyelenggaraan pemerintahan yang baik. Aparatur pemerintah harus mempertanggungjawabkan seluruh aktivitas dan pelaksanaan kerjanya kepada publik. Dalam konteks organisasi pemerintahan sendiri, akuntabilitas publik merupakan pemberian informasi atas aktivitas dan kinerja pemerintah kepada pihak-pihak yang berkepentingan. Penekanan utama akuntabilitas publik adalah pemberian informasi kepada publik dan konstituen lainnya yang menjadi pemangku kepentingan (stakeholder). Akuntabilitas publik (Mahmudi, 2002) juga terkait dengan kewajiban untuk menjelaskan dan menjawab pertanyaan mengenai apa yang telah, sedang, dan direncanakan akan dilakukan organisasi sektor publik.

\section{Pengaruh Pemantauan (PT) terhadap APKDD}

Pemantauan adalah proses yang menentukan kualitas kinerja pengendalian intern sepanjang waktu. Mewujudkan pemantauan yang baik dilakukan dengan pemantauan terus menerus, pemantauan proses kegiatan sehari-hari, evaluasi berkala, kelemahan diteliti lebih lanjut, prosedur tindak lanjut temuan, dan temuan dievaluasi, ditanggapi, dilaksanakan.

Hasil penelitian ini mendukung PP nomor 60 tahun 2008 (Republik Indonesia, 2008), menyatakan pimpinan instansi pemerintah wajib melakukan pemantauan SPI. Pemantauan SPI dilaksanakan melalui pemantauan berkelanjutan, evaluasi terpisah, dan tindak lanjut rekomendasi hasil audit dan reviu lainnya.

SPI berpengaruh positif terhadap akuntabilitas pengelolaan keuangan desa, artinya semakin diterapkannya SPIP yang salah satu unsurnya pemantauan maka hal tersebut akan meningkatkan akuntabilitas pengelolaan keuangan dana desa (Yudianto \& Ekasari, 2017); dan (Widyatama, Lola, \& Diarespati, 2017).

\section{Pengaruh LP, PR, KP, IK, serta PT terhadap APKDD}

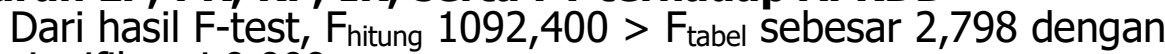
signifikansi 0,000

$<0.05$. Ini berarti secara simultan lingkungan pengendalian, penilaian risiko, kegiatan pengendalian, informasi dan komunikasi, pemantauan pengendalian berpengaruh positif dan signifikan terhadap akuntabilitas pengelolaan keuangan dana desa. 66,30\% akuntabilitas pengelolaan keuangan dana desa di Kecamatan Sembawa Kabupaten 
Banyuasin Provinsi Sumatera Selatan dipengaruhi oleh SPIP, sedangkan sisanya dipengaruhi oleh faktor-faktor lain.

SPIP berpengaruh positif terhadap akuntabilitas pengelolaan keuangan desa, artinya semakin diterapkannya SPIP, akan meningkatkan akuntabilitas pengelolaan keuangan dana desa (Republik Indonesia, 2008); (Yudianto \& Ekasari, 2017); dan (Widyatama, Lola, \& Diarespati, 2017). Strengthening public sector accountability as an important consequence of government policies and their relevance to governance could improve the quality of financial reporting and strengthen the foundation of internal (Afiah \& Azumi, 2015). Efektifitas pengendalian intern berpengaruh positif dan signifikan terhadap good governance (Martini, Sari, \& Wardhani, 2015).

Kondisi tersebut sejalan dengan pernyataan bahwa pemerintah desa (Republik Indonesia, 2014) dan (Republik Indonesia, 2014) harus menggunakan asas pengelolaan keuangan desa yaitu keuangan desa dikelola berdasarkan asas-asas transparan, akuntabel, parsisipatif serta dilakukan dengan tertib dan disiplin anggaran. Indikator yang dominan perlu diperhatikan pada dimensi transparansi adalah kemudahan publik dalam mengakses informasi, dimana instansi perlu untuk menjamin ketersediaan informasi yang berkualitas (Martini, Sari, Maria, \& Thoyib, 2016).

Keuangan Desa adalah semua hak dan kewajiban Desa yang dapat dinilai dengan uang serta segala sesuatu berupa uang dan barang yang berhubungan dengan pelaksanaan hak dan kewajiban Desa (BPKP, 2016). Pengelolaan Keuangan Desa meliputi keseluruhan kegiatan yang terkait perencanaan, pelaksanaan, penatausahaan, pelaporan, dan pertanggungjawaban keuangan desa. Laporan keuangan menggambarkan kondisi keuangan dan hasil usaha suatu perusahaan pada saat tertentu atau jangka waktu tertentu (Harahap, 2009). Jenis laporan keuangan dana desa adalah laporan realisasi pelaksanaan APBDesa, laporan pertanggungjawaban realisasi pelaksanaan APBDesa, laporan realisasi penggunaan dana, laporan pertanggungjawaban realisasi pelaksanaan APBDesa.

\section{SIMPULAN}

Untuk mencapai akuntabilitas pengelolaan keuangan desa diperlukan pengendalian atas kegiatan yang dilakukan. Pengendalian dilaksanakan dengan berpedoman kepada SPIP. SPIP berfungsi sebagai pedoman penyelenggaraan dan tolok ukur pengujian efektifitas penyelenggaraan kegiatan-kegiatan suatu organisasi pemerintahan dengan mempertimbangkan aspek biaya dan manfaat, sumber daya manusia, kejelasan kriteria pengukuran efektifitas dan perkembangan teknologi serta dilakukan secara komprehensif.

Perangkat desa Kecamatan Sembawa disarankan untuk meningkatkan pengetahuannya baik dengan melanjutkan pendidikan maupun rutin mengikuti pelatihan terkait akuntansi desa, dana desa 
maupun keterampilan khusus lainnya. Masyarakat desa sebaiknya dilibatkan secara aktif terkait pengelolaan dana desa mulai dari perencanaan hingga pertanggungjawaban. Hal ini untuk tercapainya asas pengelolaan dana desa yaitu akuntabel, transparan, partisipatif dan tertib.

Peneliti selanjutnya dapat memperluas wilayah penelitian di Kecamatan lain, menambah responden dengan melibatkan seluruh perangkat desa. Disarankan juga untuk menggali dan mempertimbangkan variabel-variabel lain yang diduga berpengaruh langsung maupun tidak langsung terhadap akuntabilitas pengelolaan dana desa seperti peran perangkat desa, pemanfaatan teknologi informasi, dan komitmen organisasi.

\section{Daftar Pustaka}

Aliniar, D., dan S. Wahyuni. 2017. "Pengaruh Mekanisme Good Corporate Governance (GCG) dan Ukuran Perusahaan Terhadap Kualitas dan Pengungkapan Sustainability Report pada Perusahaan Terdaftar di BEI". Kompartemen, Vol. 15, No. 1, hlm.

Aziz, A. 2014. "Analisis Pengaruh Good Corporate Governance (GCG) Terhadap Kualitas Pengungkapan Sustainability Report". Jurnal Audit dan Akuntansi, Vol. 3, No. 2, hlm: 65-84.

BAPEPAM. 2001. Keputusan Direksi Pt Bursa Efek Jakarta No: KEP315/BEJ/07-2001 tentang Ketentuan Umum Pencatatan Efek Bersifat Ekuitas di Bursa.

Carroll, A. B. 1991. "The Pyramid of Corporate Social Responsibility: Toward the Moral Management of Organizational Stakeholders". Business Horizons, Vol. 34, No. 3, hlm: 39-48.

Fernandez-Feijoo, B., S. Romero, dan S. Ruiz. 2012. "Effect of Stakeholders' Pressure on Transparency of Sustainability Reports within the GRI Framework ". Journals of Bussiness Ethics, Vol., No. 122, hlm: 53-63.

GRI. 2016. Sustainability Report Disclosure Standart.

Hamudiana, A., dan T. Achmad. 2017. "Pengaruh Tekanan Stakeholder Terhadap Transparansi Laporan Berkelanjutan PerusahaanPerusahaan di Indonesia". Journals of Accounting, Vol. 6, No. 4, hlm: 1-11.

Hasanah, N. m., D. Syam, dan A. W. Jati. 2015. "Pengaruh Corporate Governance terhadap Pengungkapan Sustainability Report pada Perusahaan di Indonesia". Jurnal Reviu Akuntansi Keuangan, Vol. 5, No. 1, hlm: 771-720.

Indonesia, R. 2007. Undang-Undang No. 40 Tahun 2007 tentang Perseroan Terbatas

Jenawan, S., dan Juniarti. 2015. "Pengaruh Pengungkapan Sustainability Reporting terhadap Respon Investor". Business Accounting Review, Vol. 3, No. 1, hlm. 
Khafid, M., dan Mulyaningsih. 2015. "Kontribusi Karakteristik Perusahaan dan Corporate Governance Terhadap Publikasi Sustainability Report". Jurnal Ekonomi dan Keuangan, Vol. 19, No. 3, hlm: 340359.

Kurniawan, T., H. Sofyani, dan E. Rahmawati. 2018. "Pengungkapan Sustainability Report dan Nilai Perusahan: Studi Empiris di Indonesia dan Singapura". Jurnal Ilmiah Akuntansi, Vol. 16, No. 1, hlm: 1-20.

Nasir, A., E. Ilham, dan V. I. Utara. 2014. "Pengaruh Karakteristik Perusahaan dan Corporate Governance Terhadap Pengungkapan Sustainability Report pada Perusahaan LQ45 yang Terdaftar". Jurnal Ekonomi, Vol. 22, No. 1, hlm.

Perindustrian, K. 2015. Pedoman Standar Penyusunan Industri Hijau $(S I H)$.

Rudyanto, A., dan S. V. Siregar. 2018. "The Effect of Stakeholder Pressure and Corporate Governance on the Quality of Sustainability Report ". International Journal of Ethics and Systems, Vol., No., hlm.

Sari, M. P. Y., dan Marsono. 2013. "Pengaruh Kinerja Keuangan, Ukuran Perusahaan dan Corporate Governance Terhadap Pengungkapan Sustainability Report". Journal of Accounting, Vol. 2, No. 3, hlm: $1-10$.

Sari, N. A., B. Artinah, dan Safriansyah. 2017. "Sustainability Report dan Nilai Perusahaan di Bursa Efek Indonesia". Jurnal Spread, Vol. 7, No. $1, \mathrm{hlm}$.

Sholihin, M., dan D. Ratmono. 2013. Analisis SEM-PLS dengan WarpPLS3.0 untuk Hubungan Nonlinier dalam Penelitian Sosial dan Bisnis. Yogyakarta: Andi Offset.

Simbolon, J., dan M. Sueb. 2016. "Pengaruh Pengungkapan Sustainability Report Terhadap Kinerja Keuangan Perusahaan (Studi Empiris pada Perusahaan Tambang dan Infrastruktur Subsektor Energi yang Terdaftar di BEI Tahun 2010-2014)". Simposium Nasional Akuntansi XIX, Vol., No., hlm: 1-30.

Singgih, M., L. Farida, dan R. A. Iwanda. 2017. "Determinan Tingkat Pengungkapan Tanggung Jawab Sosial Perusahaan Manufaktur Sub Sektor Makanan Dan Minuman di BEI". Bisnis dan Manajemen, Vol. 11, No. 3, hlm: 259-270.

Siregar, R. M. M. 2017. "Pengaruh Good Corporate Governance Dan Kepemilikan Saham Publik Terhadap Tingkat Pengungkapan Corporate Social Responsibility". Jurnal Profita, Vol. 6, No. 2, hlm.

Sutedi, A. 2012. Good Corporate Governance. Jakarta: Sinar Grafika.

Thomsen, S., T. Pedersen, dan H. K. Kvist. 2006. "Blockholder Ownership: Effects on Firm Value in Market and Control Based Governance Systems". Journal of Corporate Finance, Vol. 12, No. 2, hlm: 246269.

Trinanda, S. M., M. Yahdi, dan N. Rizal. 2018. "Analisis Pengaruh Size, Profitabilitas Dan Leverage Terhadap Corporate Social 
Responsibility Disclosure (Studi Empiris Pada Perusahaan Jasa Sektor Property Dan Real Estate Yang Terdaftar Di Bursa Efek Indonesia Tahun 2016)". Progress Conference, Vol. 1, No. 1, hlm. Wulanda, R. D. P. 2017. "Pengaruh Karakteristik Perusahaan Dan Corporate Governance Terhadap Publikasi Sustainability Report". JOM Fekom, Vol. 4, No. 1, hlm. 